\title{
The carbonic system distribution and fluxes in the NE Atlantic during Spring
} 1991

\author{
A.F. RÍOS ${ }^{1}$, F.F. PÉREZ1 ${ }^{1}$ and T.R. ANDERSON ${ }^{2}$ \\ ${ }^{1}$ Instituto de Investigaciones Marinas, consejo Superior de Investigaciones \\ Cientificas (CSIC), Eduardo Cabello, 6, 36208 Vigo, Spain. \\ 2 James Rennell Centre for Ocean Circulation, Natural Environment Research \\ Council, Gamma House, Chilworth Research Centre, Chilworth, Southampton, SO1 \\ $7 N S, U K$.
}

\section{INTRODUCTION}

The role of the oceans in fixing and sequestering anthropogenic $\mathrm{CO}_{2}$ emissions is a topical issue (e.g. Takahashi, 1989; Fraga and Pérez, 1990). In order to study the oceanic carbon cycle it is necessary to examine the factors which influence the rate of carbon uptake from the atmosphere, and how carbon is then exported from the upper ocean and then regenerated at depth. The air-sea exchange of carbon has been extensively researched in different areas and seasons to provide information on the importance of the ocean in climate change (Andrié et al., 1986; Oudot et al., 1987; Anderson et al., 1990; Garçon et al., 1989; Murphy et al., 1991). The North Atlantic Ocean has been proposed as a major sink for atmospheric $\mathrm{CO}_{2}$ (Brewer, 1978; Roos and Gravenhorst, 1984; Takahashi, 1989; Merlivat et al., 1991).

The exchange of carbon between atmosphere and ocean depends on the $\mathrm{CO}_{2}$ partial pressure $\left(\mathrm{pCO}_{2}\right)$ difference and the exchange coefficient $(\mathrm{k})$. The oceanic $\mathrm{pCO}_{2}$ depends on physical factors such as temperature, and, very importantly, the marine phytoplankton which use $\mathrm{CO}_{2}$ for growth, lowering the partial pressure. The greatest reduction in $\mathrm{pCO}_{2}$ occurs during the spring bloom. Watson et al. (1991) related $\mathrm{pCO}_{2}$ with physical (temperature) and biological (chlorophyll) variables, finding that in the region $47-60^{\circ} \mathrm{N}, 20^{\circ} \mathrm{W}$ the air-sea flux is strongly modulated by biological activity and is variable on short spatial scales, during the spring of 1989. Modelling studies (e.g. Taylor et al., 1991) have also been used to study the progression of the spring bloom and how it affects $\mathrm{pCO}_{2}$ in surface waters. Wind speed is the main factor which influences the exchange coefficient, although sea state is also important (Liss and Merlivat, 1986). Its value has been determined using wind tunnel experiments (Broecker et al., 1978; Merlivat and Memery, 1983) and in situ in the ocean using the radon method (Peng et al., 1979; Smithie et al., 1985). 
If the ocean is to be an effective sink for $\mathrm{CO}_{2}$, then carbon must be transported away from the surface and sequestered at depth. This transport occurs via the gravitational settling of biogenic debris produced in the photic zone, a process known as the "biological carbon pump" (Takahashi, 1989). The biogenic debris consists of "soft" organic compounds and hard skeletonic material. The latter could be calcareous (e.g. Foraminifera) or siliceous (e.g. frustules of diatoms). Most of the soft material regenerates in the upper waters of the oceans, whereas the dissolution of calcareous skeletons takes place predominantly in deeper waters (Takahashi, 1989). Studies of remineralisation of organic matter have been made by means of direct observations of the increase of $\mathrm{CO}_{2}$ in the water column (Brewer, 1978) or by establishing models to obtain stochiometric equations between inorganic carbon and nitrate, phosphate and dissolved oxygen (Papaud and Poisson, 1986).

This study aims to investigate the potential of the North Atlantic as a sink for atmospheric $\mathrm{CO}_{2}$ by examining the carbonic system, using data collected in the spring of 1991 on cruise "Darwin-58". The distribution of $\mathrm{pCO}_{2}$ and chlorophyll is studied, and the flux of $\mathrm{CO}_{2}$ between atmosphere and ocean calculated. The remineralisation of organic matter and redissolution of calcareous skeletonic matter is examined in vertical sections representative of the study area.

\section{MATERIALS AND METHODS}

The "Darwin-58" cruise was carried out in the NE Atlantic as part of the UK VIVALDI project which is a component of UK World Ocean Circulation Experiment (WOCE). The cruise track is illustrated in Fig. 1, showing a total of four latitudinal and five meridional sections. Nineteen stations were studied between $48^{\circ} 37.1^{\prime} \mathrm{N}$, $9^{\circ} 20.7^{\prime} \mathrm{W}$ and $39^{\circ} 10.2^{\prime} \mathrm{N}, 26^{\circ} 43.3^{\prime} \mathrm{W}$.

At each station a CTD cast with a General Oceanics, 24 by 10 litre bottle rosette, a Chelsea Instruments fluorometer, and a Sea Tech $1 \mathrm{~m}$ path transmissometer were deployed. Samples from the water bottles were taken to measure chlorofluorocarbons, oxygen, nutrients (silicate, phosphate and nitrate), salinity, $\mathrm{pH}$, alkalinity and chlorophyll. The methodology is described in Pollard et al. (1991), Smythe-Wright et al (1992, 1993); data can be found in Griffiths et al. (1992).

Discrete samples were taken from the non-toxic supply every 30 minutes to determine $\mathrm{pH}$ at approximately hourly intervals, which coincided with the Seasoar at the surface. Chlorophyll was determined using continuous readings from a wet lab fluorometer. The temperature and salinity of non-toxic supply of sea-water was measured by the Seabird thermosalinograph every 30 seconds. 
A Metrohm $654 \mathrm{pH}$ meter with a Ross (Orion 8104) combination glass electrode was used to determine $\mathrm{pH}$. The temperature of the samples was measured using a platinum resistance thermometer to correct for the effect of temperature on pH (Pérez and Fraga, 1987a). All of the $\mathrm{pH}$ values were corrected to a standard temperature of $15^{\circ} \mathrm{C}$.

Alkalinity was measured using a Metrohm E-410 $\mathrm{pH}$ meter with a separate glass electrode and a reference electrode connected to an automatic burette and an impulsomat. Potentiometric titrations were carried out with $\mathrm{HCl}$ to a final $\mathrm{pH}$ of 4.44. The electrodes were standardised using an NBS buffer of $\mathrm{pH} 7.413$ and checked using an NBS buffer of 4.008 . This method of determining alkalinity has a precision of $0.1 \%$ (Pérez and Fraga, 1987b).

Total inorganic carbon and $\mathrm{pCO}_{2}$ were calculated from alkalinity and $\mathrm{pH}$ using published equations for the oceanic carbon system (Mehrbach et al, 1973; Weiss, 1974). The alkalinity of surface seawater was calculated fitting the specific alkalinity data of casts against pressure $\left(r^{2}=0.93\right)$ with 65.4 specific alkalinity at zero metres.

The wind stress was measured on board using a Multimet for mean meteorology located in the main mast.

A zooplankton net was lowered to $100 \mathrm{~m}$ immediately after the CTD was brought back on board at each station. Samples were emptied into jars with $10 \%$ formalin for identification back on land.

\section{RESULTS}

\subsection{Distributions in vertical sections}

Distributions of temperature, salinity, carbonic system parameters and nutrients are shown for two representative sections, along $42^{\circ} \mathrm{N}$ and $20^{\circ} \mathrm{W}$, in Figs. 2 and 3 . Examination of the thermohaline structure between the surface and 4000 metres highlights the different water masses in the sampled zone. The surface layer is 100 to 200 metres deep. Below this layer there is Eastern North Atlantic Central Water (ENAW) which extends up to a further 750 metres. Although not obvious from Figs. 2 and 3, ENAW has two components: subtropical and subpolar (Ríos et al, 1992). The most saline water is Mediterranean Water (MW), which is centred mainly at a depth of about 1000 metres, and was observed to spread from the southeast to the northwest, reaching $43^{\circ} \mathrm{N}$. The tongue of MW restricts the penetration of ENAW of polar origin (Fig. 3), as was seen by Ríos et al. (1992) in the North Atlantic Ocean. Labrador Sea Water (LW), characterised by salinities lower than 34.9 , is located between 1800 and 2000 metres. Its influence is evident in the $42^{\circ} \mathrm{N}$ section between 
$28^{\circ} \mathrm{W}$ and $16^{\circ} \mathrm{W}$, and in the $20^{\circ} \mathrm{W}$ section north of $42^{\circ} \mathrm{N}$. Below 2500 metres North Atlantic Deep Water (NADW) occurs, distinguishable by its uniform temperature and salinity.

\subsubsection{Regeneration of carbon}

The vertical distribution of inorganic carbon with depth throughout the study area is shown in Fig. 4a. This distribution reflects the uptake of $\mathrm{CO}_{2}$ by phytoplankton for photosynthesis in surface waters and its subsequent regeneration deeper in the water column. Two phases can be distinguished: a rapid increase of $\Sigma \mathrm{CO}_{2}$ near the surface tapering to almost no increase below $1000 \mathrm{~m}$, and a second increase, occurring at a slower rate, commencing at approx. $2300 \mathrm{~m}$. To help interpret these observations, $\Sigma \mathrm{CO}_{2}$ is plotted against alkalinity (Fig. 4b). When skeletonic carbon $\left(\mathrm{CaCO}_{3}\right)$ dissolves, alkalinity increases by two equivalents for each mole increase in carbon. On the other hand, when soft tissue remineralises a decrease of one equivalent of alkalinity occurs for each mole of nitrate formed (Ríos et al., 1989). The expected slope of an alkalinity $/ \Sigma \mathrm{CO}_{2}$ plot is then (Broecker and Peng, 1982):

$$
\frac{\Delta \mathrm{A}}{\Delta \Sigma \mathrm{CO}_{2}}=2 \frac{\Delta \mathrm{C}_{\mathrm{org}}}{\Delta \mathrm{C}_{\mathrm{CaCO} 3}+\Delta \mathrm{C}_{\mathrm{org}}}-\frac{\Delta \mathrm{C}_{\mathrm{CaCO} 3}}{\mathrm{R} \cdot \Delta \mathrm{C}_{\mathrm{CaCO} 3}+\Delta \mathrm{C}_{\mathrm{org}}}
$$

where $\mathrm{A}$ is alkalinity, $\mathrm{C}_{\mathrm{CaCO} 3}$ is hard (skeletonic) carbon, $\mathrm{C}_{\text {org }}$ is soft tissue carbon, and $\mathrm{R}$ is the ratio of carbon to nitrogen in soft tissue. Rearrangement of Eq. 1 permits the fractions of soft and hard material in biogenic material to be predicted:

$$
\frac{\Delta \mathrm{C}_{\mathrm{CaCO} 3}}{\Delta \mathrm{C}_{\mathrm{org}}}=\frac{\Delta \mathrm{A} / \Delta \Sigma \mathrm{CO}_{2}+1 / \mathrm{R}}{2-\Delta \mathrm{A} / \Delta \Sigma \mathrm{CO}_{2}}
$$

Calculated slopes for the $\mathrm{A} / \Sigma \mathrm{CO}_{2}$ relationships shown in Fig. $4 \mathrm{~b}$ are 0.141 and 0.952 for data in depth ranges 0-2300 $\mathrm{m}$ and $>2300 \mathrm{~m}$ respectively. Despite the involvement of different water masses and the variation in the composition of organic matter with depth (Tanoue, 1985), we used the classic Redfield C:N ratio of 6.625 (Redfield et al., 1963) to estimate values of the $\Delta \mathrm{C}_{\mathrm{CaCO} 3} / \Delta \mathrm{C}_{\text {org }}$ ratio for the two depth ranges of $0.16(<2300 \mathrm{~m})$ and $1.05(>2300 \mathrm{~m})$. In other words, $14 \%$ of regenerated carbon in the upper depth range derives from hard skeletonic matter, whereas this increases to $51 \%$ for the deeper range. The upper ocean is supersaturated with calcium carbonate (Broecker and Peng, 1982), and therefore the regeneration of inorganic carbon is dominated by soft tissue remineralisation. Most soft tissue carbon is remineralised within the top $1000 \mathrm{~m}$ of the water column, as shown by plots of $\mathrm{pH}$ and nitrate in Figs. 2 and 3. Below about $2300 \mathrm{~m}$ calcium carbonate starts to dissolve more readily 
(because of the increased pressure and decreased temperature), and the regeneration of carbon is dominated by skeletal dissolution. This is reflected by a marked increase in alkalinity (Figs. 2 and 3).

Silicon is also exported as opaline compounds in biogenic matter (mostly in diatom frustules) and redissolved in the deep ocean. As for carbonate, most opaline silica dissolution occurs below about $2300 \mathrm{~m}$ (Figs 2 and 3).

\subsubsection{Covariance between $\mathrm{CO}_{2}$ and nutrients}

Here, we develop a model to predict $\Sigma \mathrm{CO}_{2}$ from nutrients (nitrate and silicate) in the water column. Because of the regeneration pattern of carbon described above, one would expect good correlations between $\mathrm{pH}$ and nitrate, and alkalinity and silicate (Figs. 2 and 3). Once $\mathrm{pH}$ and alkalinity have been calculated, then a theoretical value for $\Sigma \mathrm{CO}_{2}\left(\Sigma \mathrm{CO}_{2}\right.$ pred $)$ can be predicted using standard equations (Mehrbach et al., 1973, and Weiss, 1974). Note that the model only predicts $\Sigma \mathrm{CO}_{2}$ variations resulting from the regeneration of carbon, and not those caused by different water masses mixing within the study area. In other words, predicted $\Sigma \mathrm{CO}_{2}$ must be compared with observed values which have been normalised to salinity.

Normalised alkalinity shows a high correlation with silicate (Fig. 5):

$$
\mathrm{A}_{(\text {norm })}=(2286 \pm 3)+(1.52 \pm 0.02) * \mathrm{SiO}_{4(\text { norm })} \quad \mathrm{r}^{2}=0.96
$$

Similarly, $\mathrm{pH}$ (corrected to $15^{\circ} \mathrm{C}$ ) shows a high correlation with nitrate (Fig. 6):

$$
\mathrm{pH}_{15}=(8.258 \pm 0.016)-(0.01432 \pm 0.0001) * \mathrm{NO}_{3(\text { norm })} \mathrm{r}^{2}=0.96
$$

The success of the model at reproducing observed $\Sigma \mathrm{CO}_{2}\left(\Sigma \mathrm{CO}_{2 \text { real }}\right)$ is shown in Fig. 7. The error in the prediction is typically less than $1 \mu \mathrm{mol} \mathrm{C} \mathrm{kg}^{-1}$.

Previous studies (Broecker and Peng, 1982; Poisson and Cheng, 1987) have provided models to predict $\Sigma \mathrm{CO}_{2}$ from nitrate. We have also derived this model from our data:

$$
\Sigma \mathrm{CO}_{2(\text { norm })}=(2001 \pm 9)+(8.79 \pm 0.08) * \mathrm{NO}_{3(\text { norm })} \quad \mathrm{r}^{2}=0.97
$$

The covariance $\left(r^{2}=0.97\right)$ is only slightly lower than that of the model described above $\left(r^{2}=0.98\right)$ : Eqs. 3 and 4 .

\subsection{Surface distributions}


The temperature-salinity (T-S) properties of surface water, measured every half hour throughout the cruise, are shown in Fig. 8. Reference curves for WNAW and ENAW according to Iselin (1936) and Fiuza (1984) respectively are superimposed. Two separate sets of data points can be distinguished: one above the WNAW curve and the second more or less on the ENAW curve. The observations positioned above the WNAW represent mixing between surface water and WNAW over winter. This water is situated to the west of $21^{\circ} \mathrm{W}$. The other group of observations reflects winter mixing between surface water and ENAW, and is situated between $12^{\circ} \mathrm{W}$ and $21^{\circ} \mathrm{W}$. The surface distributions of variables of interest to this study are shown in Fig. 9. The temperature distribution shows the boundary between eastern surface water (ESW) and western surface water (WSW) at $13.5^{\circ} \mathrm{C}$. The divide between the two groups of observations shown in Fig. 8 is located at $21^{\circ} \mathrm{W}$.

\subsubsection{Distributions of chlorophyll and $\mathrm{pCO}_{2}$.}

The distribution of chlorophyll (Fig. 9) shows high values (with a maximum of $8.98 \mathrm{mg} \mathrm{m}^{-3}$ ) in ESW (i.e. to the east of $21^{\circ} \mathrm{W}$ ), and much lower values (less than 1.5 $\mathrm{mg} \mathrm{m}^{-3}$ ) in the west (WSW). It is not surprising that biological dynamics are not the same between the two water masses, because of their differing properties. In the cooler waters to the east of $21^{\circ} \mathrm{W}$, the phytoplankton spring bloom was occurring during the observational period. To the west of $21^{\circ} \mathrm{W}$, the lower chlorophyll concentrations indicate that the bloom had already occurred, or had not yet been initiated. The distribution of surface nitrate throughout the study area (Fig. 9) shows that nitrate values in the WSW were still quite high, suggesting that the phytoplankton bloom had not yet got underway. Zooplankton samples taken during the cruise were dominated by copepods in the ESW, with a very marked transition to salps in WSW (Fig. 10). Copepods are generally thought to be the dominant large grazers on phytoplankton (e.g. Parsons and Lalli, 1988). Salps, however, are important suspension feeders (Alldredge and Madin, 1982), and we are of the opinion that they were feeding on the decaying remains of a post-bloom scenario. The relatively high nitrate concentrations in the WSW might then be explained by zooplankton grazing preventing phytoplankton from fully exploiting nitrate during the bloom.

In some areas, $\mathrm{pCO}_{2}$ shows a distribution that coincides roughly with chlorophyll (Fig. 9). The minimum values observed were about $300 \mathrm{ppm}$, located between $43^{\circ}$ and $45^{\circ} \mathrm{N}$ at $16^{\circ} \mathrm{W}$. They correspond with a nucleus of chlorophyll at the zone where the planktonic bloom is most evident. The best correlation between $\mathrm{pCO}_{2}$ 
and chlorophyll for any of the latitudinal sections was found along $16^{\circ} \mathrm{W}$ (Fig. 11). The two variables show a distinct negative correlation $\left(\mathrm{r}^{2}=0.46\right)$ :

$$
\mathrm{pCO}_{2}=(353 \pm 12)-(8.9 \pm 1.3)[\mathrm{Chl}] \quad \mathrm{r}^{2}=0.46
$$

When chlorophyll is zero, the $\mathrm{pCO}_{2}$ of the surface water is in equilibrium with the atmosphere. This value of $353 \mathrm{ppm}$ compares favourably with Takahashi's (1989) figure of $350 \mathrm{ppm}$, which he estimated assuming an annual increase of $0.35 \%$ in atmospheric $\mathrm{CO}_{2}$.

If all five latitudinal sections are examined, however, correlations between chlorophyll and $\mathrm{pCO}_{2}$ are less obvious. The correlations $\left(\mathrm{r}^{2}\right)$ for the $12^{\circ}, 16^{\circ}, 20^{\circ}, 24^{\circ}$ and $28^{\circ} \mathrm{W}$ sections are $0.003,0.46,0.05,0.10$ and 0.02 respectively. The $\mathrm{r}^{2}$ value for all the data put together is 0.02 . Two sets of factors may contribute to weak correlations between chlorophyll and $\mathrm{pCO}_{2}$ : environmental (chemical and physical) and biological. The physical and chemical environment, and in particular temperature and wind, affects $\mathrm{pCO}_{2}$. An in situ temperature increase of $1^{\circ} \mathrm{C}$ causes an in situ $\mathrm{pH}$ decrease of 0.0127 , resulting in a $\mathrm{pCO}_{2}$ increase of about $15 \mathrm{ppm}(4.3 \%)$. The wide variation in temperature $\left(12^{\circ}\right.$ to $\left.17^{\circ} \mathrm{C}\right)$ throughout the study area (Fig. 9) therefore causes large variations in $\mathrm{pCO}_{2}$ in surface waters (once the $\mathrm{pCO}_{2}$ of these waters has equilibriated with the atmosphere), independently of biological processes. The carbon flux between atmosphere and ocean increases with wind speed (see below), and thus in windy areas a poor correlation between $\mathrm{pCO}_{2}$ and chlorophyll might be expected. Another contributory factor may be biological processes. If the phytoplankton bloom has been grazed down by zooplankton (i.e. a post-bloom situation is reached), and the grazed material is not immediately recycled to $\Sigma \mathrm{CO}_{2}$ in surface waters (e.g. it is exported via particulate matter or maintained in zooplankton biomass), then a close correlation between $\mathrm{pCO}_{2}$ and chlorophyll would not be expected. In the western part of the study area (WSW) all these factors may be important: wind (in the northwest), temperature and biological effects. The situation is less clear further east (ESW). In addition to the factors described above, the upwelling of water (REF) with high $\Sigma \mathrm{CO}_{2}$ may be causing the relatively high $\mathrm{pCO}_{2}$ values observed there (particularly at $12^{\circ} \mathrm{W}$ ). Over the study area as a whole, it is not surprising that a poor correlation is found between chlorophyll and $\mathrm{pCO}_{2}$ because of all these interacting factors.

\subsection{2 $\mathrm{CO}_{2}$ flux between atmosphere and ocean.}

The exchange of carbon between the atmosphere and ocean, $F\left(m m o l ~ m^{-2} \mathrm{~d}^{-1}\right)$, can be calculated using the following equation: 


$$
\mathrm{F}=0.24 \mathrm{kS}\left(\mathrm{pCO}_{2} \mathrm{oc}-\mathrm{pCO}_{2} \mathrm{~atm}\right)
$$

where $\mathrm{k}\left(\mathrm{cm} \mathrm{h}^{-1}\right)$ is the exchange coefficient or "piston velocity", $\mathrm{S}\left(\mathrm{mol} \mathrm{l}^{-1} \mathrm{~atm}^{-1}\right)$ is the solubility of $\mathrm{CO}_{2}$ in seawater, $\mathrm{pCO}_{2 \mathrm{oc}}$ is $\mathrm{pCO}_{2}$ in the ocean, and $\mathrm{pCO}_{2} \mathrm{~atm}$ is the partial pressure of $\mathrm{CO}_{2}$ in air (both in $\mu \mathrm{atm}$ ). The factor 0.24 converts between units. The seasonal and inter-annual variations in the atmospheric $\mathrm{pCO}_{2}$ are small when compared to $\mathrm{pCO}_{2}$ variations in the surface ocean (Andrié et al., 1986). We therefore assumed a constant atmospheric $\mathrm{CO}_{2}$ partial pressure of 352 ppm (Fraga and Pérez, 1990; Chipman et al., 1993; Robertson et al., 1993). The value is similar to that obtained in Eq. 6 when the chlorophyll concentration is zero and the partial pressures of $\mathrm{CO}_{2}$ in the sea and atmosphere are in equilibrium.

The impact of wind speed on the exchange coefficient, $k$, must be taken into account. This relationship has been studied using a wind tunnel experiments (Broecker et al., 1978; Merlivat and Memery, 1983), and in the ocean in situ using radon (Peng et al., 1979; Smithie et al., 1985). Liss and Merlivat (1986) reviewed both these types of study, and proposed equations for $20^{\circ} \mathrm{C}$ (Schmidt number 600) which have also been used by Andrié et al., 1986 and Oudot et al., 1987. However, given that the range of temperature in our data lies between 12 and $17^{\circ} \mathrm{C}$, the equations used by Woolf and Thorpe (1991) were used:

$$
\begin{array}{ll}
\mathrm{k}=0.17 \mathrm{U}_{10}(600 / \mathrm{Sc})^{2 / 3} & \mathrm{U}<\mathrm{U}_{1} \text { : smooth water regime } \\
\mathrm{k}=\left(2.85 \mathrm{U}_{10}-9.65\right)(600 / \mathrm{Sc})^{1 / 2} & \mathrm{U}>\mathrm{U}_{1} \text { : rough water regime } \\
\mathrm{U}_{1}=9.65\left[2.85-0.17(600 / \mathrm{Sc})^{1 / 6}\right]^{-1} &
\end{array}
$$

where $\mathrm{Sc}$ is Schmidt number, and $\mathrm{U}_{10}$ is the wind speed $10 \mathrm{~m}$ above the ocean surface $\left(\mathrm{m} \mathrm{s}^{-1}\right)$. We obtain $U_{1}=3.6 \mathrm{~m} \mathrm{~s}^{-1}$ for our temperature range. We have derived the following equation relating Schmidt number to temperature, using data tabulated by Andrié et al. (1986: table 1):

$$
\log (600 / \mathrm{Sc})=-1.0687+0.05127 \mathrm{~T} \quad \mathrm{r}^{2}=0.995
$$

Positive fluxes indicate exchange from ocean to atmosphere. Calculated fluxes are shown in Fig. 12, showing uptake of carbon by the ocean. The highest rates of uptake occur in two zones. The first, located at $45^{\circ} 13^{\prime} \mathrm{N}, 16^{\circ} 04^{\prime} \mathrm{W}\left(\mathrm{F}=-6.4 \mathrm{mmol} \mathrm{C} \mathrm{m}^{-}\right.$ $\left.2 \mathrm{~d}^{-1}\right)$ is where the highest primary production was occurring, and coincides with water of subpolar origin $\left(\mathrm{ENAW}_{\mathrm{p}}\right)$. This zone was also observed by Pollard and $\mathrm{Pu}$ (1985). The second zone is at $47^{\circ} 57^{\prime} \mathrm{N}, 28^{\circ} 19^{\prime} \mathrm{W}\left(\mathrm{F}=-7.8 \mathrm{mmol} \mathrm{C} \mathrm{m}^{-2} \mathrm{~d}^{-1}\right)$, and 
coincides with the highest wind speeds (Fig. 9). Fluxes of $\mathrm{CO}_{2}$ from the ocean to the atmosphere occur in areas centred around $45^{\circ} \mathrm{N}, 12^{\circ} \mathrm{W}$ and $44^{\circ} 21^{\prime} \mathrm{N}, 27^{\circ} 30^{\prime} \mathrm{W}$.

\section{DISCUSSION}

In order to validate our results we compared our data (D58) with those collected ten years ago in the TTO (Transient Tracers in the Ocean) program, which are summarised in Tables 1 and 2. Only stations with similar geographical positions are compared (Fig. 1). At depths greater than $2000 \mathrm{~m}$ both thermohaline characteristics, alkalinity and total inorganic carbon are very similar (Table 1). Data for depths less than $2000 \mathrm{~m}$ for the TTO and D58 cruises are compared in Table 2. Differences in normalised alkalinity are only about two per thousand. Variations in normalised $\Sigma \mathrm{CO}_{2}$ are double those of alkalinity. This variation is due to a different degree of ageing (oxidation) of water masses, as can be seen from the oxygen values. On the other hand, Labrador Sea Water, which is situated at about $2000 \mathrm{~m}$, has similar values of alkalinity and $\Sigma \mathrm{CO}_{2}$ for both cruises (Table 1). However, Labrador Water sometimes shows the same ageing patterns (i.e. variations in alkalinity and $\Sigma \mathrm{CO}_{2}$ as the surface waters (Table 2). Although the methodologies for measuring $\Sigma \mathrm{CO}_{2}$ used by TTO and D58 are different, the similarity in the results shows the effectiveness of the simple and rapid method used in this study, which was developed by Pérez and Fraga $(1987 a, b)$.

Examination of the vertical sections showed that the regeneration of carbon takes place in two principal stages: 0-1000 m, and $>2300 \mathrm{~m}$. Nearly all of the soft tissue carbon remineralised in the upper $1000 \mathrm{~m}$ : oxidation of organic debris takes place preferentially in this zone (Takahashi, 1989). Similarly, Pérez et al. (in press) found high remineralisation rates in a mixing layer between 400 and $1000 \mathrm{~m}$ depth, when working off the Iberian peninsula (NE Atlantic). We calculated that $86 \%$ of regenerated carbon in the upper $1000 \mathrm{~m}$ was derived from soft tissue, by examining a plot of normalised $\Sigma \mathrm{CO}_{2}$ versus alkalinity. Despite the carbonate supersaturation of the upper ocean, we nevertheless calculated that $14 \%$ of regenerated carbon in this zone was skeletonic $\left(\mathrm{CaCO}_{3}\right)$ in origin. Broecker and Peng (1982) found this fraction to be as high as $20 \%$ in temperate surface waters. The second phase of carbon regeneration starts at approx. $2300 \mathrm{~m}$. Below this depth the regenerated carbon originating from carbonate skeletons is more important than in the upper ocean because of the effects of increased pressure and decreased temperature on carbonate dissolution. Moreover, in deep waters the residence time of hard skeletons is higher because of the small size and slow settling velocities of particles. The fraction of 
regenerated carbon arising from carbonate skeletons therefore increases to 54\%. This compares favourably with a fraction of $50 \%$ for deep waters in various oceans which Broecker and Peng (1982) derived using GEOSECS data. As for carbonate, most opaline silica dissolution occurs below about $2300 \mathrm{~m}$, below which a marked increase in silicate is seen. A simple model is developed to predict $\Sigma \mathrm{CO}_{2}$ from nutrients (nitrate and silicate) in the water column. This model reproduces the observed pattern of $\Sigma \mathrm{CO}_{2}$, showing an error typically less than $1 \mu \mathrm{mol} \mathrm{C} \mathrm{kg}^{-1}$.

A good correlation between $\mathrm{pCO}_{2}$ and chlorophyll was found along $16^{\circ} \mathrm{W}$ in this study ( $r^{2}=0.46$ : Eq. 6). Watson et al. (1991) also found good linear relationships between these variables in the NE Atlantic $\left(47-60^{\circ} \mathrm{N}, 20^{\circ} \mathrm{W}\right)$. The y-intercept of our relationship of $353 \mathrm{ppm}$ agrees well with the $\mathrm{pCO}_{2}$ in the atmosphere (Fraga and Pérez, 1990; Robertson et al., 1992; Chipman et al., 1993). The increase of $\mathrm{pCO}_{2}$ with latitude observed by Watson et al. (1991) was also found in this study. Throughout much of the study area, however, poor correlations were found between $\mathrm{pCO}_{2}$ and chlorophyll. Various factors may explain this: (i) different water masses (which have different $\Sigma \mathrm{CO}_{2}$, salinities and temperatures) were present (ii) high wind speeds (particularly in the northwest and east of the study area) cause a large atmosphere-ocean carbon flux and (iii) biological processes (particularly grazing) which impact on the chlorophyll biomass.

The exchange of carbon between atmosphere and ocean is largely controlled by the product $\mathrm{kS}$ (Eq. 7), where $\mathrm{k}$ is piston velocity and $\mathrm{S}$ is the solubility of $\mathrm{CO}_{2}$ in seawater. Merlivat et al. (1991) defined an exchange coefficient $\mathrm{K}$ as $\mathrm{K}=\mathrm{kS}$, and calculated $\mathrm{K}$ to be $0.028 \mathrm{mmol} \mathrm{m}^{-2} \mathrm{y}^{-1} \mu \mathrm{atm}^{-1}$ to the north of $40^{\circ} \mathrm{N}$ in the North Atlantic. We calculated a similar mean value over the study area for $\mathrm{K}$ from $\mathrm{S}$ and $\mathrm{k}$ (Eqs. 8-11) as $0.021 \mathrm{mmol} \mathrm{m}^{-2} \mathrm{y}^{-1} \mu_{\mathrm{atm}}^{-1}$.

The calculated mean $\mathrm{CO}_{2}$ flux from atmosphere to ocean for the period and zone sampled was $0.50 \mathrm{mmol} \mathrm{m}^{-2} \mathrm{~d}^{-1}$. This value confirms the role of the North Atlantic as a sink for atmospheric $\mathrm{CO}_{2}$ (Brewer et al., 1989; Takahashi et al., 1989). This mean value is, however, slightly lower than values found by other authors (Table 3 ), although these other values are not specific to the spring bloom period, and cover different geographical ranges. Our mean value is closest to Merlivat et al's (1991) value of $0.68 \mathrm{mmol} \mathrm{m}^{-2} \mathrm{~d}^{-1}$, which they estimated from data of Maier-Reimer and Hasselman (1987). Schlitzer (1989) developed a model of carbon exchange between atmosphere and ocean in the North Atlantic $\left(10^{\circ}-50^{\circ} \mathrm{N}\right)$ using annually averaged data (Levitus, 1982) and calculated fluxes to the ocean of 0.39 to $1.48 \mathrm{mmol} \mathrm{m}^{-2} \mathrm{~d}^{-1}$. Our mean value is within these limits.

The 1989 spring bloom in the North Atlantic $\left(47^{\circ}-60^{\circ} \mathrm{N}, 20^{\circ} \mathrm{W}\right)$ was modelled by Taylor et al. (1992). Predicted oceanic carbon uptake from the atmosphere was 9 
mmol m $\mathrm{m}^{-2} \mathrm{~d}^{-1}$. This is higher than a value of $4.9 \mathrm{mmol} \mathrm{m}^{-2} \mathrm{~d}^{-1}$ which we calculated in this study for the area where the bloom was most evident $\left(45^{\circ} \mathrm{N}, 16^{\circ} \mathrm{W}\right)$. Our value is closer to the mean flux of $5.9 \mathrm{mmol} \mathrm{m}^{-2} \mathrm{~d}^{-1}$ found by Chipman et al. (1993) at $47^{\circ} \mathrm{N}$ $20^{\circ} \mathrm{W}$ in spring 1989 .

Acknowledgements - We would like to thank the master, officers and crew of RRS Charles Darwin and all participants in the "Darwin-58" cruise for their help. The Spanish participation in this cruise was possible thanks to an invitation of Dr. R. Pollard and was financed partially by MAST 0017-C(EDB) and MAR88-245 projects supported by EEC and CICYT respectively. We also thank Trinidad Rellán for drawing the figures, Dr. F. Fraga for his suggestions and comments and Gavin H. Tilstone for correcting the text.

\section{REFERENCES}

ALLDREDGE, A.L. and L.P. MADIN (1982). Pelagic tunicates: unique herbivores in the marine plankton. BioSci., 32, 655-663.

ANDERSON, L.G., D. DYRSSEN and E.P. JONES (1990). An Assessment of the Transport of Atmospheric $\mathrm{CO}_{2}$ into the Arctic Ocean. J. Geophys. Res., 95, 1703-1711

ANDRIÉ, C., C. OUDOT, C. GENTHON and L. MERLIVAT (1986). CO 2 fluxes in the Tropical Atlantic during FOCAL cruises. J. Geophys. Res., 91, 1174111755 .

BREWER, P.G. (1978). Direct observations of the oceanic $\mathrm{CO}_{2}$ increase. Geophysical Research Letters, 5, 997-1000.

BREWER, P.G. and J.C. GOLDMAN (1976). Alkalinity changes generated by phytoplankton growth. Limnol. Oceanogr., 21, 108-117.

BREWER, P.G., C. GOYET and D. DYRSSEN (1989). Carbon dioxide transport by ocean currents at $25 \varnothing \mathrm{N}$ Latitude in the Atlantic Ocean. Science, 247, 477-479. 
BROECKER, H.C., J. PETERMANN and W. SIEMS (1978). The influence of windwave tunnel including the effects of monolayers. J. Mar. Res., 36, 595-610.

BROECKER, W.S. and T.H. PENG (1982). Tracers in the sea. Eldigio Press, Palisades, New York, 690 pp.

CHIPMAN, D.W., J. MARRA and T. TAKAHASHI (1993). Primary production at $47^{\circ} \mathrm{N}$ and $20^{\circ} \mathrm{W}$ in the North Atlantic Ocean: a comparison between the ${ }^{14} \mathrm{C}$ incubation method and the mixed layer carbon budget. Deep-Sea Res., 40, 151169.

ESTRADA, M. (1989). Phytoplankton - Inorganic Carbon uptake and respiratory ETS activity. In "The expedition Antarktis VII/3 (EPOS LEG 2) of $R V$ 'Polarstern' in 1988/89" Ed. Hempel, Schalk and Smetacker. Berichtezur Polarforschung, 65, 88-91.

FIUZA, A.F.G. (1984). Hidrologia e dinamica das aguas costeiras de Porgugal. These Doctoral Science. University Lisbonne. Portugal, 294 pp.

FRAGA, F. and F.F.PÉREZ (1990). El agua de mar como sumidero del exceso de carbono atmosférico. Boletín Academia Galega de Ciencias, 9, 5-13.

GARÇON, V.C., L. MARTINON, C. ANDRIÉ, P. ANDRICH and J.F. MINSTER (1989). Kinematics of $\mathrm{CO}_{2}$ fluxes in the Tropical Atlantic Ocean during the 1983 Northern summer. J. Geophys. Res., 94, 855-870.

GRIFFITHS, G., S. CUNNINGHAM, M. GRIFFITHS, R.T. POLLARD, H. LEACH, S. HOLLEY, R. PAYLOR, T.W.N. HAINE, A.F. RIOS, S.G. ALDERSON, R.K. LOWRY, P. SMITH, M. PRESTON, T.J.P. GWILLIAM, J. SMITHERS, S. KEENE, J. HEMMINGS and T.R. ANDERSON (1992). CTD oxygen, tracer and nutrient data from RRS Charles Darwin cruises 58/59 in the NE Atlantic as part of Vivaldi '91. IOSDL Report, 296, 51 pp.

HARVEY, J. 1982. O-S relationship and water masses in the eastern North Atlantic. Deep-Sea Research., 29, 1021-1033.

ISELIN, C.O'D. 1936. A study of the circulation of the western North Atlantic. Ppers in Physical Oceanography and Meteorology, 4, 101 pp. 
KEELING, C.D., R.B. BACASTOW, A.E. BAINBRIDGE, C.A. EKDAHL, P.R. GUENTHER and L.S. WATERMAN (1976). Atmospheric carbon dioxide variations at Mauna Loa Observatory, Hawaii. Tellus, 28, 438-551.

KIRCHMAN, D.L., Y. SUZUKI, C. GARSIDE and H.W. DUCKLOW (1991). High turnover rates of dissolved organic carbon during a spring phytoplankton boom. Nature, 352, 612-614.

LISS, P. and MERLIVAT (1986). Air-sea gas exchange rates: Introduction and synthesis, in The Role of Air-Sea Exchange in Geochemical Cycling, Adv. Sci. Inst. Ser., edited by P. Buat-Ménard, D. Reidel Pub. Co., Dordrecht, Holland, 113-127.

MEHRBACH, C., C.H. CULBERSON, J.E. HAWLEY and R.M. PYTKOWICZ (1973). Measurements of the apparent dissociation constant of carbonic acid in seawater at amospheric pressure. Limnology and Oceanography, 18, 897-907.

MERLIVAT, L., J. ETCHETO and J. BOUTIN (1991). CO 2 exchange at the air-sea interface: time and space variability. Adv. Space. Res., 11, 77-85

MERLIVAT, L. and L. MEMERY (1983). Gas exchange an air-water interface: Experimental results and modeling of bubble contribution to transfer. $J$. Geophys. Res., 88, 707-724.

MURPHY, P.P., R.A. FEELY, R.H. GAMMON, D.E. HARRISON, K.C. KELLY and L.S. WATERMAN (1991). Assessment of the air-sea exchange of $\mathrm{CO}_{2}$ in the South Pacific during Austral autumn. J. Geophys. Res., 96, 20455-20465.

OUDOT, C., C. ANDRIÉ and Y. MONTEL (1987). Evolution du $\mathrm{CO}_{2}$ océanique et atmosphérique sur la période 1982-1984 dans l'Atlantique tropical. Deep-Sea Research, 34, 1107-1137

PAPAUD, A and A. POISSON (1986). Distribution of dissolved $\mathrm{CO}_{2}$ in the Red Sea and correlations with other geochemical tracers. J. Mar. Res., 44, 385-402. 
PARSONS, T.R., and C.M. LALLI (1988). Comparative oceanic ecology of the plankton communities of the subarctic Atlantic and Pacific oceans. Oceanogr. Mar. Biol. Annu. Rev., 26, 317-359.

PENG, T.H., W.S. BROECKER, G.G. MATHIEU and Y.H. LI (1979). Radon evasion rates in the Atlantic and Pacific oceans as determined during GEOSECS Program. J. Geophys. Res., 84, 2471-2486.

PÉREZ, F.F., C. MOURIÑO, F. FRAGA and A.F. RÍOS. Displacement of water masses and remineralization rates off the Iberian peninsula by nutrient anomalies. J. Mar. Res. (submitted)

PÉREZ, F.F. and F. FRAGA. 1987a. The pH measurements in seawater on the NBS scale. Marine Chemistry, 21, 315-327.

PÉREZ, F.F. and F. FRAGA. 1987b. A precise and rapid analytical procedure for alkalinity determination. Marine Chemistry, 21, 169-182.

POLLARD, R.T., H. LEACH and G. GRIFFITHS. 1991. RRS Charles Darwin cruises 58 \& 59, 25 Apr - 16 May; 18 May - 10 Jun 1991. IOSDL, Cruise Report, 228, 49 pp.

REDFIELD, A.C., KETCHUM, B.H. and RICHARDS, F.A. (1963). The influence of organisms on the composition of sea-water. pp. 26-77 in M.N. Hill (ed.), The Sea, Vol. 2, Interscience.

RÍOS, A.F., FRAGA, F. and PÉREZ, F. (1989). Estimation of coefficients for the calculation of "NO", "PO", and "CO", starting from the elemental compostion of natural phytoplankton. Scient. Mar. 53, 779-784.

RÍOS, A.F., F.F. PÉREZ and F. FRAGA. 1992. Water masses in the upper and middle North Atlantic Ocean east of the Azores. Deep-Sea Research, 39, 645658.

ROBERTSON, J.E., A.J. WATSON, C. LANGDON, R.D. LING and J.W. WOOD (1993). Diurnal variation in surface $\mathrm{pCO}_{2}$ and $\mathrm{O}_{2}$ at $60^{\circ} \mathrm{N}, 20^{\circ} \mathrm{W}$ in the North Atlantic. Deep-Sea Res., 40, 409-422. 
ROOS, M. and G.GRAVENHORST (1984). The increase in oceanic carbon dioxide and the net $\mathrm{CO}_{2}$ flux into the North Atlantic. J. Geophys. Res., 89, 8181-8193.

SCHLITZER, R. (1989). Modeling the nutrient and carbon cycles of the North Atlantic 2. New production, particle fluxes, $\mathrm{CO} 2$ exchange, and the role of organic nutrients. J. Geophys. Res., 94, 12781-12794.

SMITHIE, W.M., T. TAKAHASHI and D.W. CHIPMAN (1985). Gas exchange and $\mathrm{CO}_{2}$ flux in the Tropical Atlantic ocean determined from ${ }^{222} \mathrm{Rn}$ and $\mathrm{pCO}_{2}$ measurements. J. Geophys. Res., 90, 7005-7022.

SMYTHE-WRIGHT, D., PAYLOR, R. and HOLLEY, S.E. (1992). Chemical tracer studies at IOSDL - 3. IOSDL Rep. 302, 73 pp.

SMYTHE-WRIGHT, D., PAYLOR, R. and HOLLEY, S.E. (1993). Chemical tracer studies at IOSDL - 4. IOSDL Rep. 303, 47 pp.

TAKAHASHI, T. (1989). Only half as much $\mathrm{CO}_{2}$ as expected from industrial emissions is accumulating in the atmosphere. Could the oceans be the storehouse for the missing gas?. Oceanus, 32, 22-29.

TANOUE, E. (1985). Distribution and chemical composition of particulate matter in the Pacific sector of the Antarctic Ocean. Trans. Tokyo Univ. Fish., 6, 43-57.

TAYLOR, A.H., A.J. WATSON, M. AINSWORTH, J.E. ROBERTSON and D.R. TURNER (1991). A modelling investigation of the role of phytoplankton in the balance of carbon at the surface of the North Atlantic. Global Biogeochemical cycles, 5, 151-171.

TAYLOR, A.H., A.J. WATSON and J.E. ROBERTSON (1992). The influence of the spring phytoplankton bloom on carbon dioxide and oxygen concentrations in the surface waters of the northeast Atlantic during 1989. Deep-Sea Res., 39, $137-152$.

Transient Tracers in the Oceans North Atlantic Study. Shipboard Physical and Chemical data report 1 April-19 October (1981). Scripps Institution of Oceanography. University of California. San Diego. 2 
WATSON, A.J., C. ROBINSON, J.E. ROBINSON, P.J. LE B. WILLIAMS and M.J.R. FASHAM (1991). Spatial variability in the sink for atmospheric carbon dioxide in the North Atlantic. Nature, 350, 50-53.

WEISS, R.F. (1974). Carbon dioxide in water and seawater: the solubility of a nonideal gas. Mar. Chem., 2, 203-215.

WOOLF, D.K. and S.A. THORPE (1991). Bubbles and the air-sea exchange of gases in near-saturation conditions. J. Mar. Res., 49, 435-466. 


\section{FIGURE CAPTIONS}

Fig. 1 - Cruise track for cruise "Darwin-58", showing positions of CTD stations (circles). TTO (1981) stations are also shown (squares). The vertical sections represented in Figs. 2 and 3 are depicted as solid lines.

Fig. 2 - Distributions of temperature, salinity, carbonic system variables and nutrients in a vertical section along $42^{\circ} \mathrm{N}$.

Fig. 3 - Distributions of temperature, salinity, carbonic system variables and nutrients in a vertical section along $20^{\circ} \mathrm{W}$.

Fig. 4 - Distribution of normalised $\Sigma \mathrm{CO}_{2}$ throughout the study area: a) variation with depth b) plotted against normalised alkalinity.

Fig. 5 - Relationship between alkalinity and salinity. Regression line is Eq. 3.

Fig. 6 - Relationship between $\mathrm{pH}$ at $15^{\circ} \mathrm{C}$ and nitrate. Regression line is Eq. 4.

Fig. 7 - Comparison of predicted $\Sigma \mathrm{CO}_{2}\left(\Sigma \mathrm{CO}_{2 \text { pred }}\right)$ using the model and observed $\Sigma \mathrm{CO}_{2}\left(\Sigma \mathrm{CO}_{2 \text { real }}\right)$.

Fig. 8 - Temperature-salinity properties of surface water throughout the study area. Crosses are data to the west of $21^{\circ} \mathrm{W}$ and squares correspond to data to the east of this longitude. Curves for WNAW and ENAW according to Iselin (1936) and Fiuza (1984) are superimposed.

Fig. 9 - Surface-water distributions of temperature, salinity, chlorophyll, nitrate and factors affecting the air-sea carbon flux, thoughout the study area.

Fig. 10 - Major constituents of zooplankton samples collected at each CTD station. Symbols are: circles - copepods, stars - salps and jellies, squares - chaetognaths, triangles - euphausiids.

Fig. 11 - Latitudinal variation of pCO2 and chlorophyll along $16^{\circ} \mathrm{W}$.

Fig. 12 - Calculated atmosphere-ocean carbon fluxes during the cruise in $\mathrm{mmol} \mathrm{m}^{-2} \mathrm{~d}^{-}$

1 . Negative values represent uptake by the ocean. 
Table 1

Comparison of termohaline characteristics and carbonic system between Darwin-58 cruise (D58) and Transient Traces in Ocean (TTO) in deep waters (>2000 m)

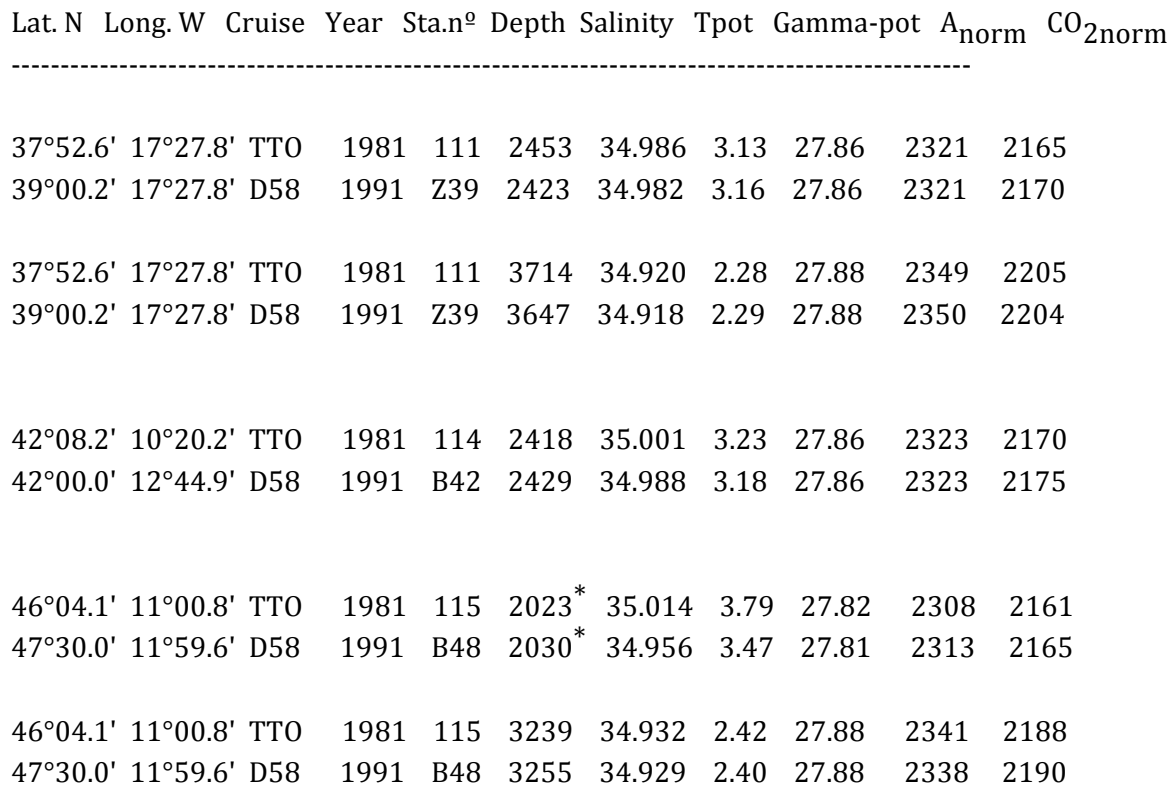

${ }^{*}$ LW (Labrador Sea Water)

$\mathrm{A}_{\text {norm }}$ Alkalinity normalized at salinity 35

$\mathrm{CO}_{2 \text { norm }} \mathrm{CO}_{2}$ normalized at salinity 35 
Table 2

Comparison of termohaline characteristics, carbonic system and oxygen between Darwin-58 cruise (D58) and Transient Traces in Ocean (TTO) at depths less than $2000 \mathrm{~m}$.

\begin{tabular}{|c|c|c|c|c|c|c|c|c|c|}
\hline Lat. N Long. W Cruise & Year & $\operatorname{ta} n^{\circ}$ & Depth & Salinity 1 & Tpot & Gamm & pot $A_{n o}$ & $\mathrm{rm} \mathrm{CO}$ & $\mathrm{O}_{2 \text { nor }}$ \\
\hline $37^{\circ} 52.6^{\prime} 17^{\circ} 27.8^{\prime}$ ТТО & 1981 & 111 & 342 & 35.622 & 11.96 & 27.08 & 2293 & 2084 & 223 \\
\hline $39^{\circ} 00.2^{\prime} 17^{\circ} 27.8^{\prime}$ D58 & 1991 & Z39 & 402 & 35.642 & 11.96 & 27.10 & 2291 & 2094 & 217 \\
\hline $37^{\circ} 52.6^{\prime} 17^{\circ} 27.8^{\prime}$ ТTо & 1981 & 111 & 569 & 35.532 & 10.80 & 27.23 & 2299 & 2114 & 203 \\
\hline $39^{\circ} 00.2^{\prime} 17^{\circ} 27.8^{\prime}$ D58 & 1991 & Z39 & 604 & 35.527 & 10.84 & 27.22 & 2293 & 2113 & 203 \\
\hline $42^{\circ} 08.2^{\prime} 10^{\circ} 20.2^{\prime}$ ТTО & 1981 & 114 & 992 & 36.061 & 10.77 & 27.64 & 2309 & 2123 & 185 \\
\hline $42^{\circ} 00.0^{\prime} 12^{\circ} 44.9^{\prime}$ D 58 & 1991 & B42 & 1008 & 36.086 & 10.93 & 327.63 & 2312 & 2131 & 1181 \\
\hline $42^{\circ} 08.2^{\prime} 10^{\circ} 20.2^{\prime}$ ТTО & 1981 & 114 & $1996^{*}$ & * 35.060 & 3.98 & 27.84 & 2312 & 2158 & \\
\hline $42^{\circ} 00.0^{\prime} 12^{\circ} 44.9^{\prime}$ D 58 & 1991 & B42 & $2023^{*}$ & * 35.075 & 4.09 & 27.84 & 2316 & 2165 & \\
\hline
\end{tabular}

\footnotetext{
* LW (Labrador Sea Water)

$\mathrm{A}_{\text {norm }}$ Alkalinity normalized at salinity 35

$\mathrm{CO}_{2 \text { norm }} \mathrm{CO}_{2}$ normalized at salinity 35
} 
Table 3

Mean fluxes of $\mathrm{CO}_{2}$ between atmosphere and ocean in the North Atlantic

Year Location $\begin{gathered}\text { Mean net Flux Autor } \\ \text { mmol.m }{ }^{-2} \cdot \mathrm{d}^{-1}\end{gathered}$

1903-1973 North Atlantic $\left(0^{\circ}-40^{\circ} \mathrm{N}\right) \quad-1.20 \quad$ Roos \& Gravenhorst, 1984

" " North Atlantic $\left(0^{\circ}-80^{\circ} \mathrm{N}\right) \quad-2.93$

1986 North Atantic $\left(0^{\circ}-80^{\circ} \mathrm{N}\right) \quad-1.56^{(1)} \quad$ Merlivat et al 1991

1987 North Atantic $\left(0^{\circ}-80^{\circ} \mathrm{N}\right) \quad-0.68^{(2)}$

Spring 1991 North Atantic $\left(39^{\circ}-48^{\circ} \mathrm{N}\right) \quad-0.65 \quad$ This paper

(1) data derived of Broecker et al. (1986)

(2) data derived of Maier-Reimer and Hasselmann (1987)

(1) and ${ }^{(2)}$ The units have been transformed from gC. $\mathrm{y}^{-1}$ taking into account the surfaces (areas) given by Roos and Gravenhorts (1984). 


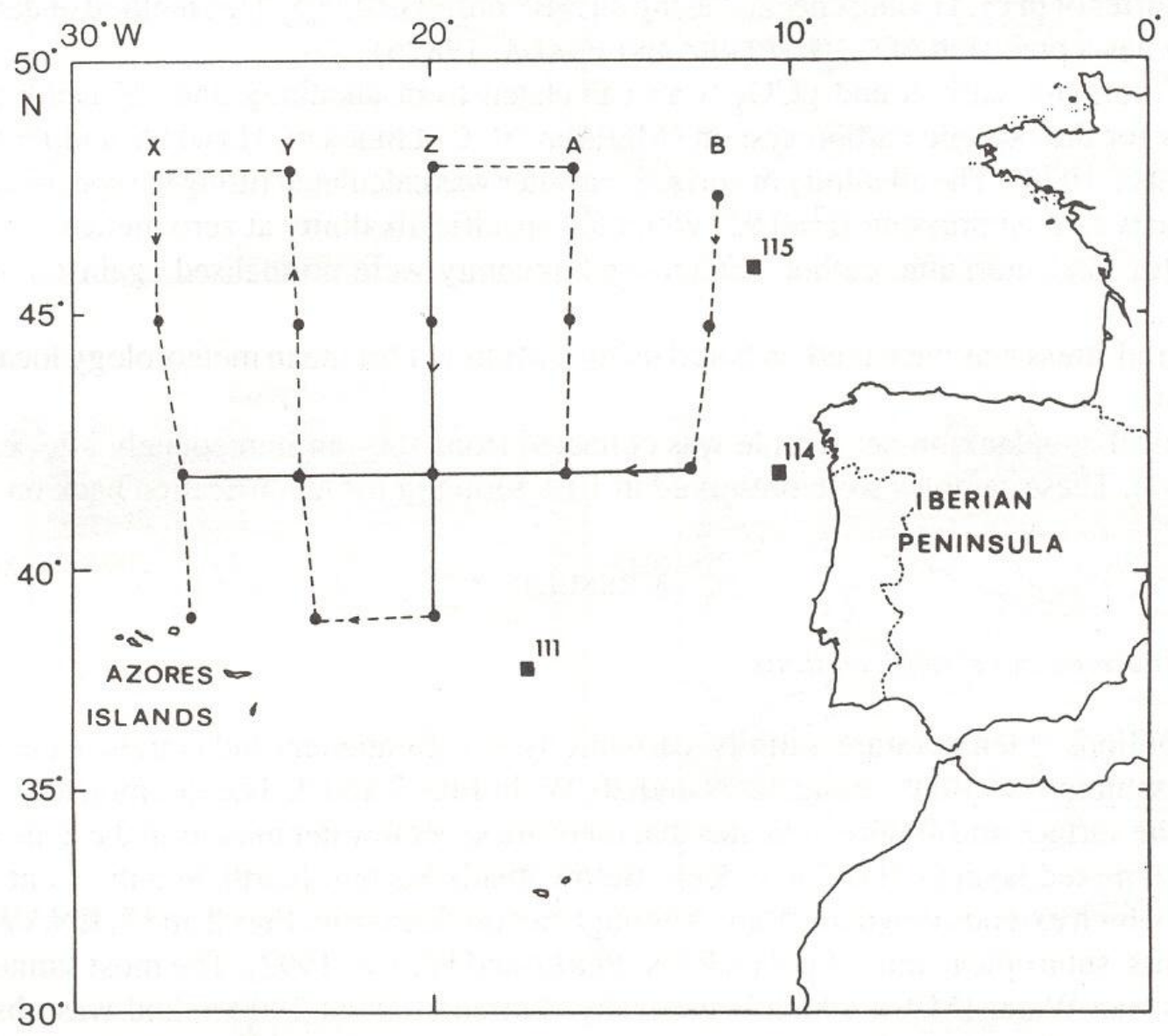

FIGURE 1 


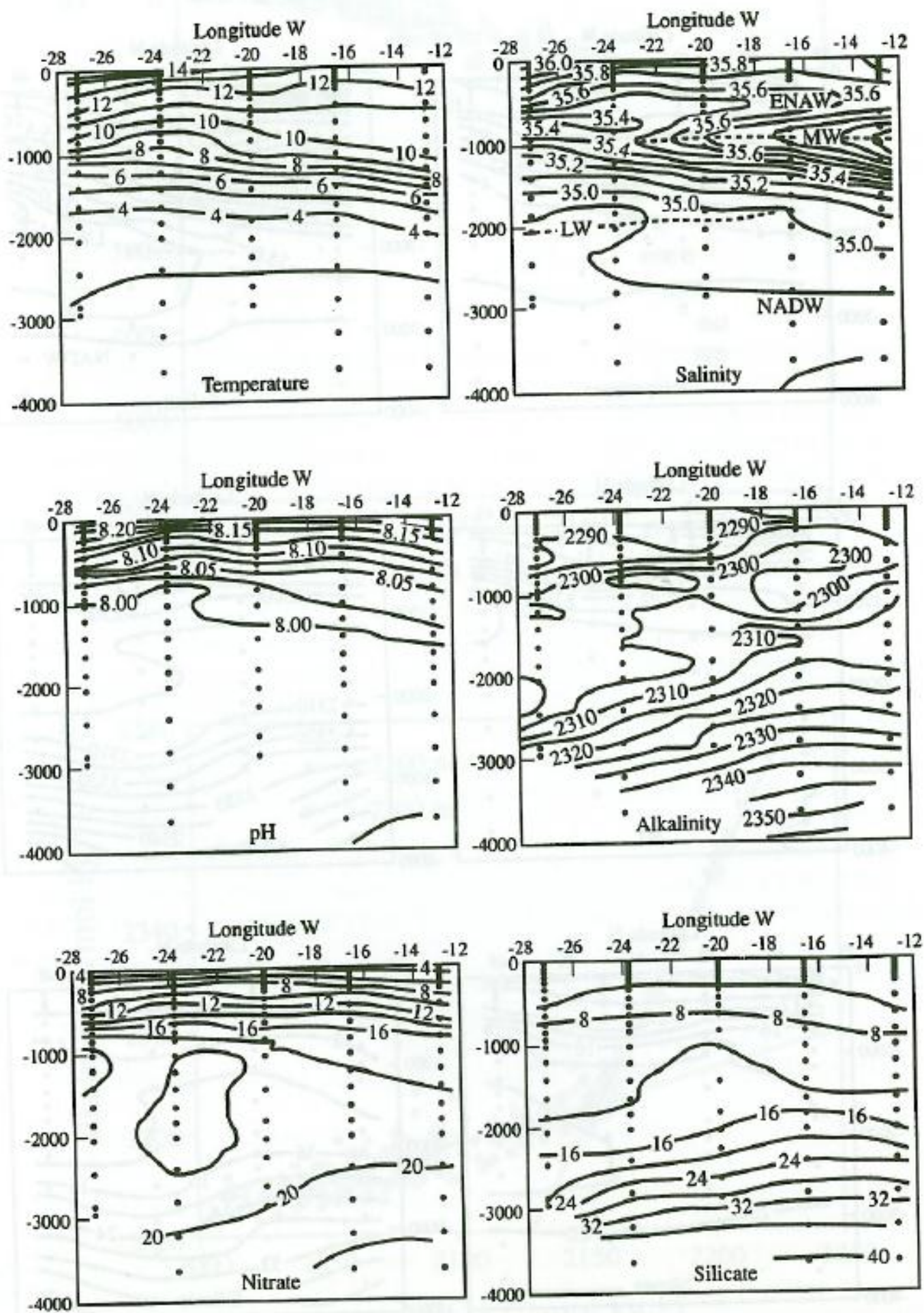

FIGURE 2 

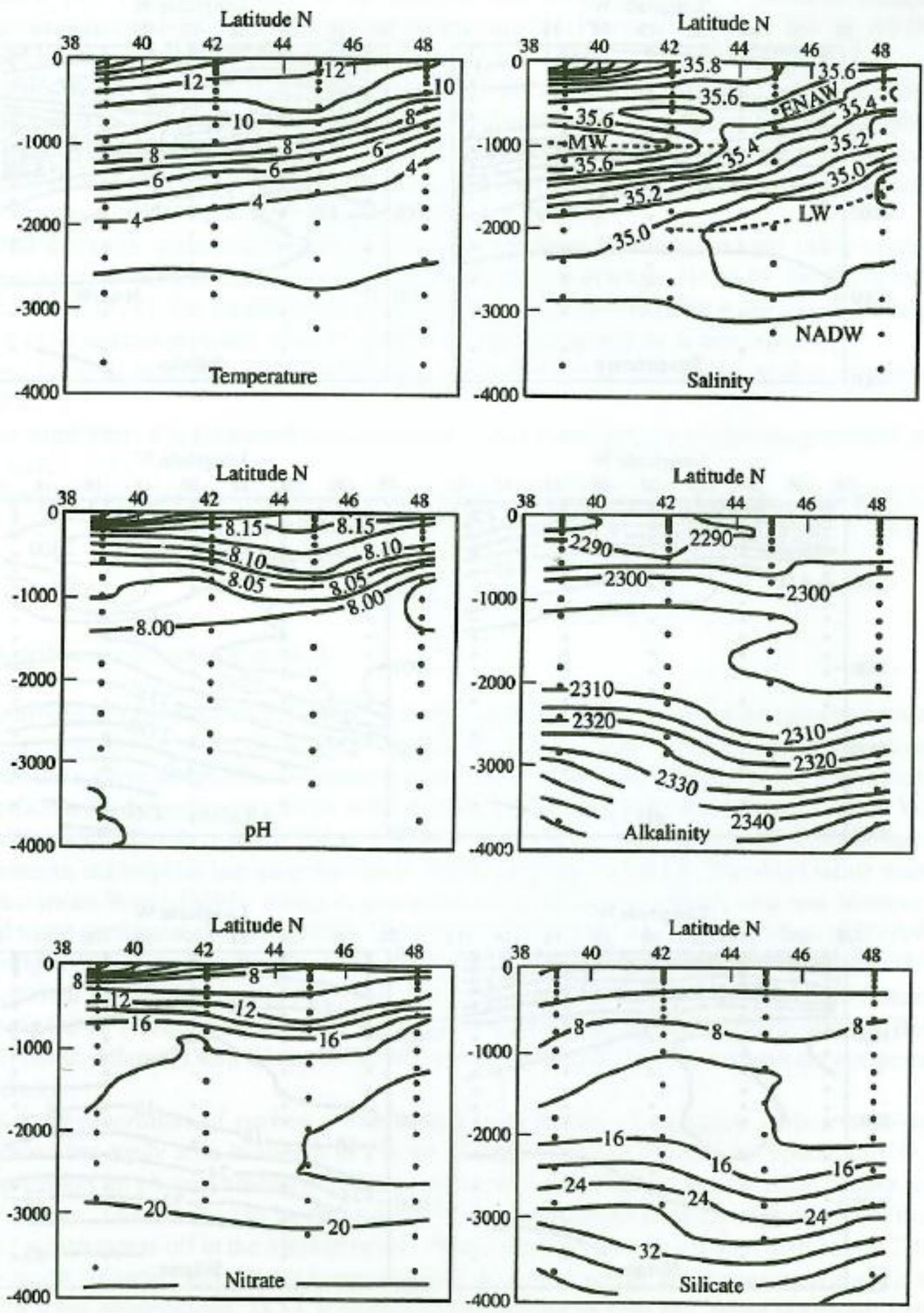

FIGURE 3 

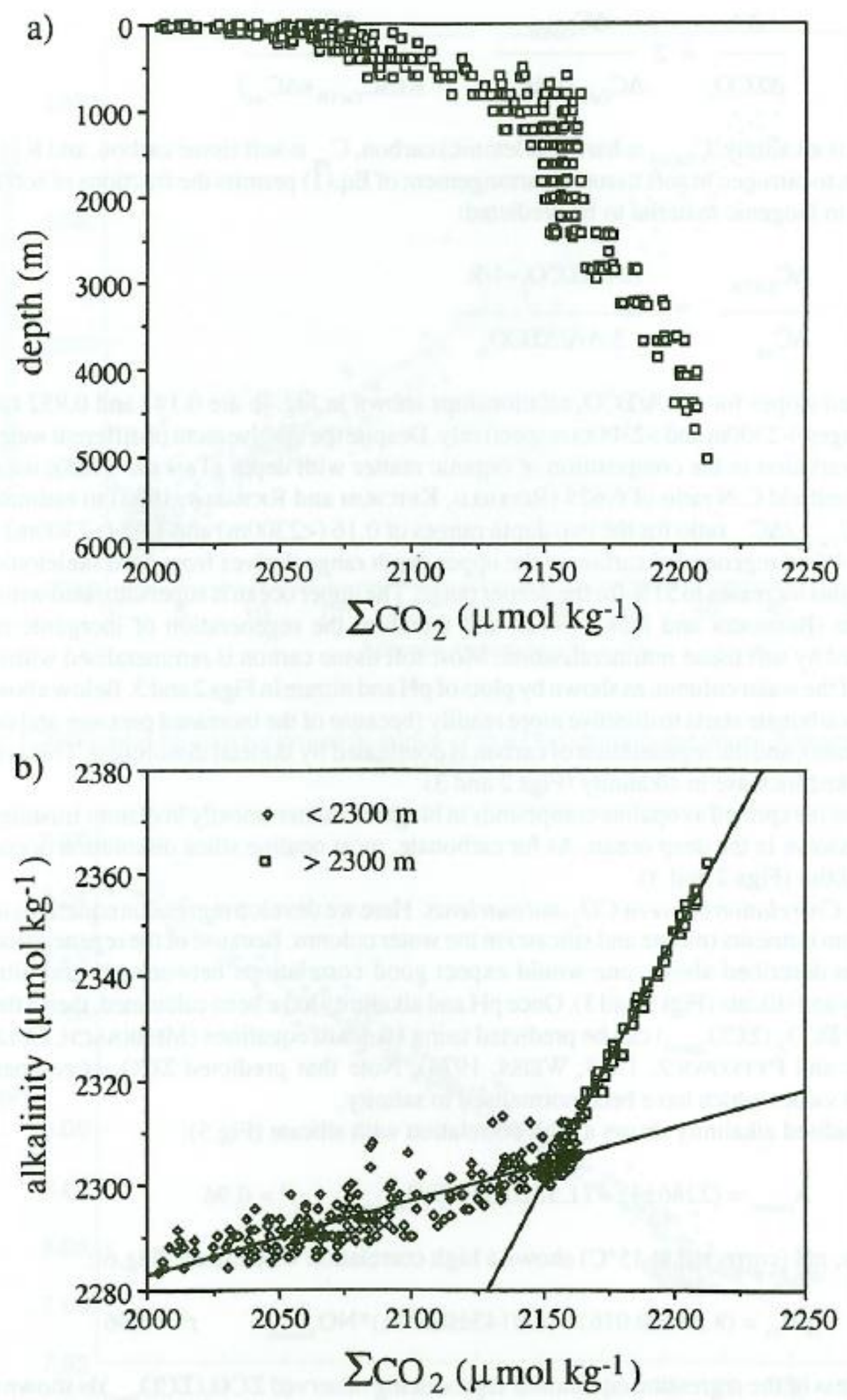

FIGURE 4 


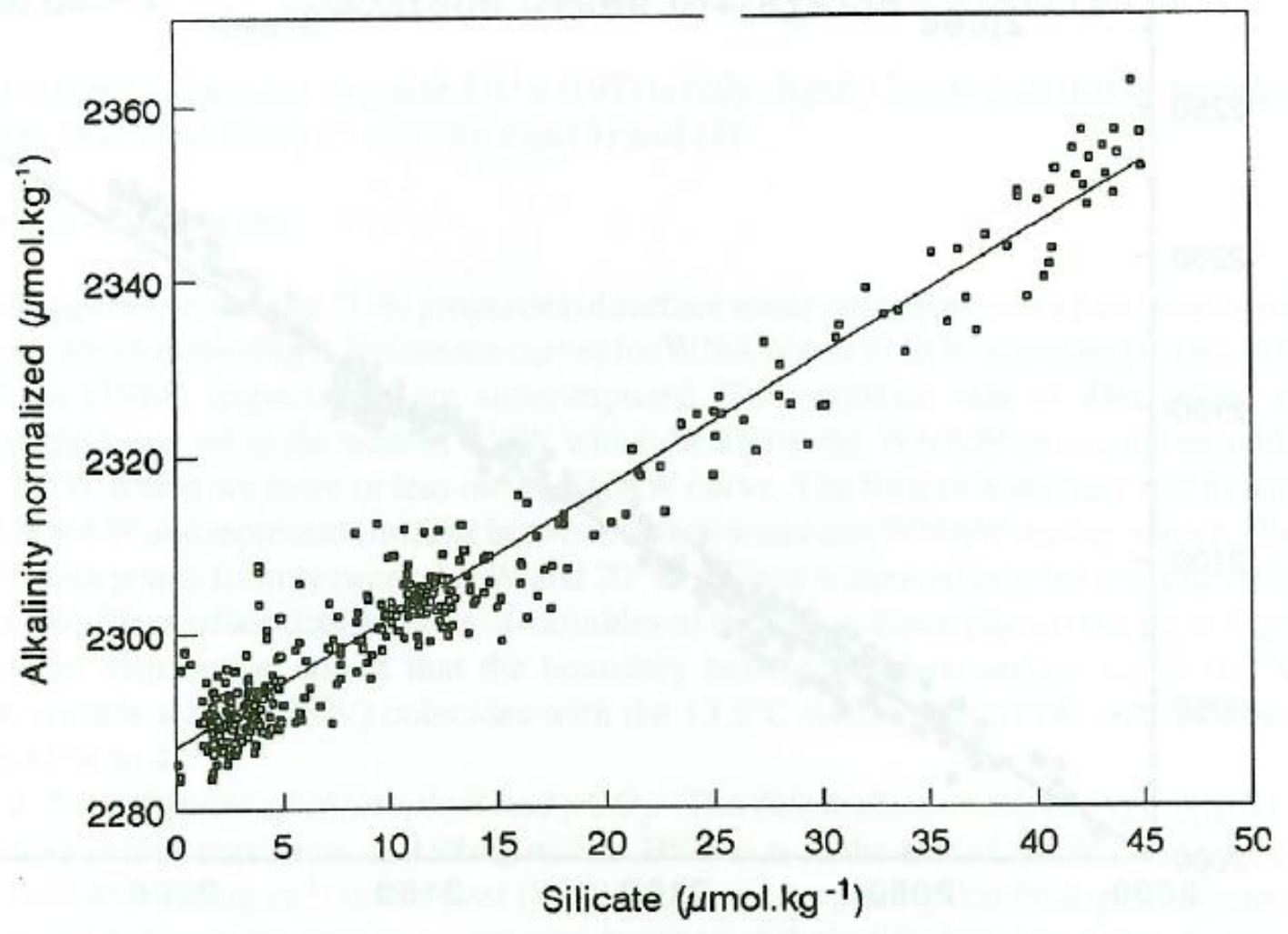

FIGURE 5 


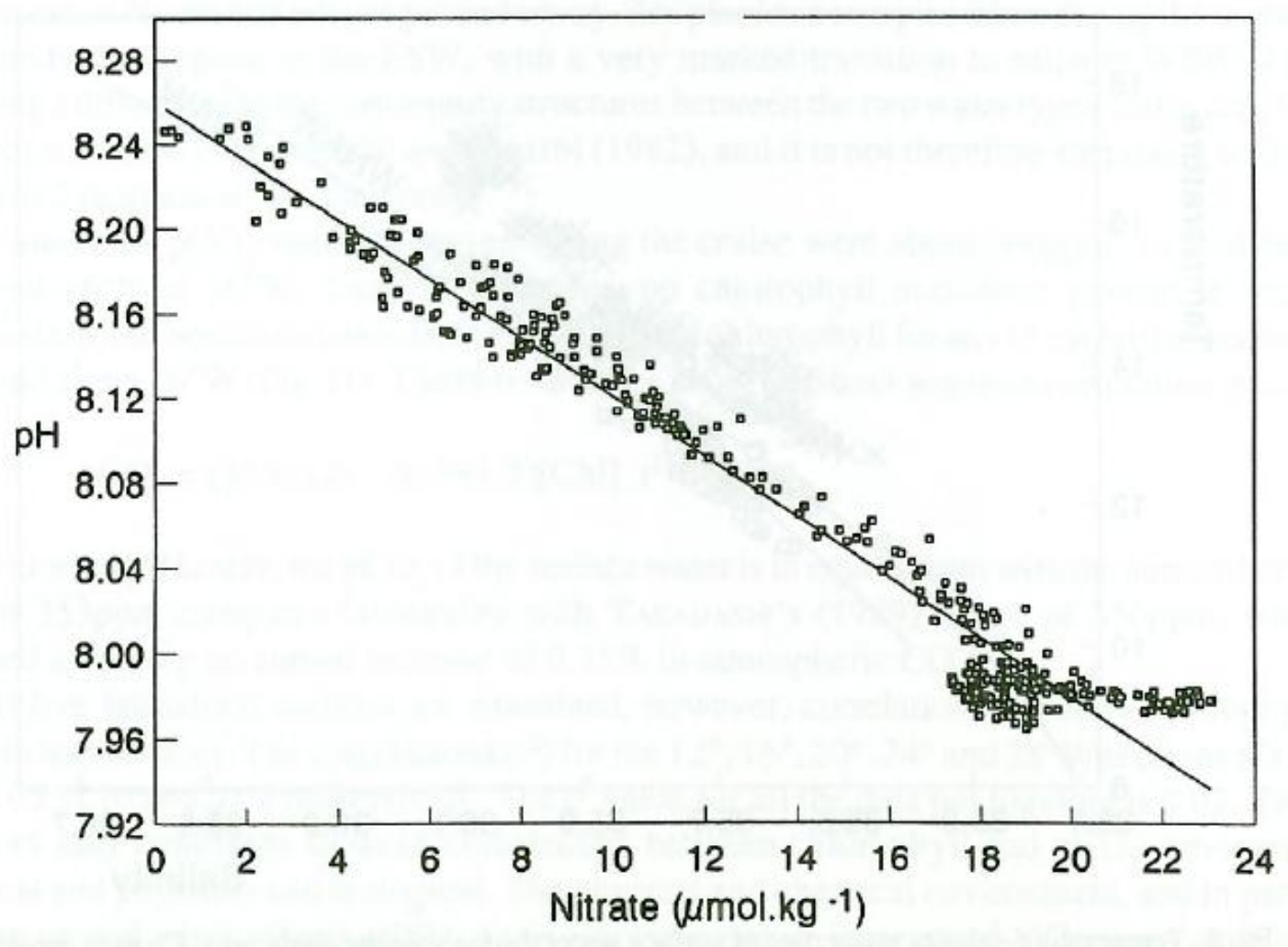

FIGURE 6 


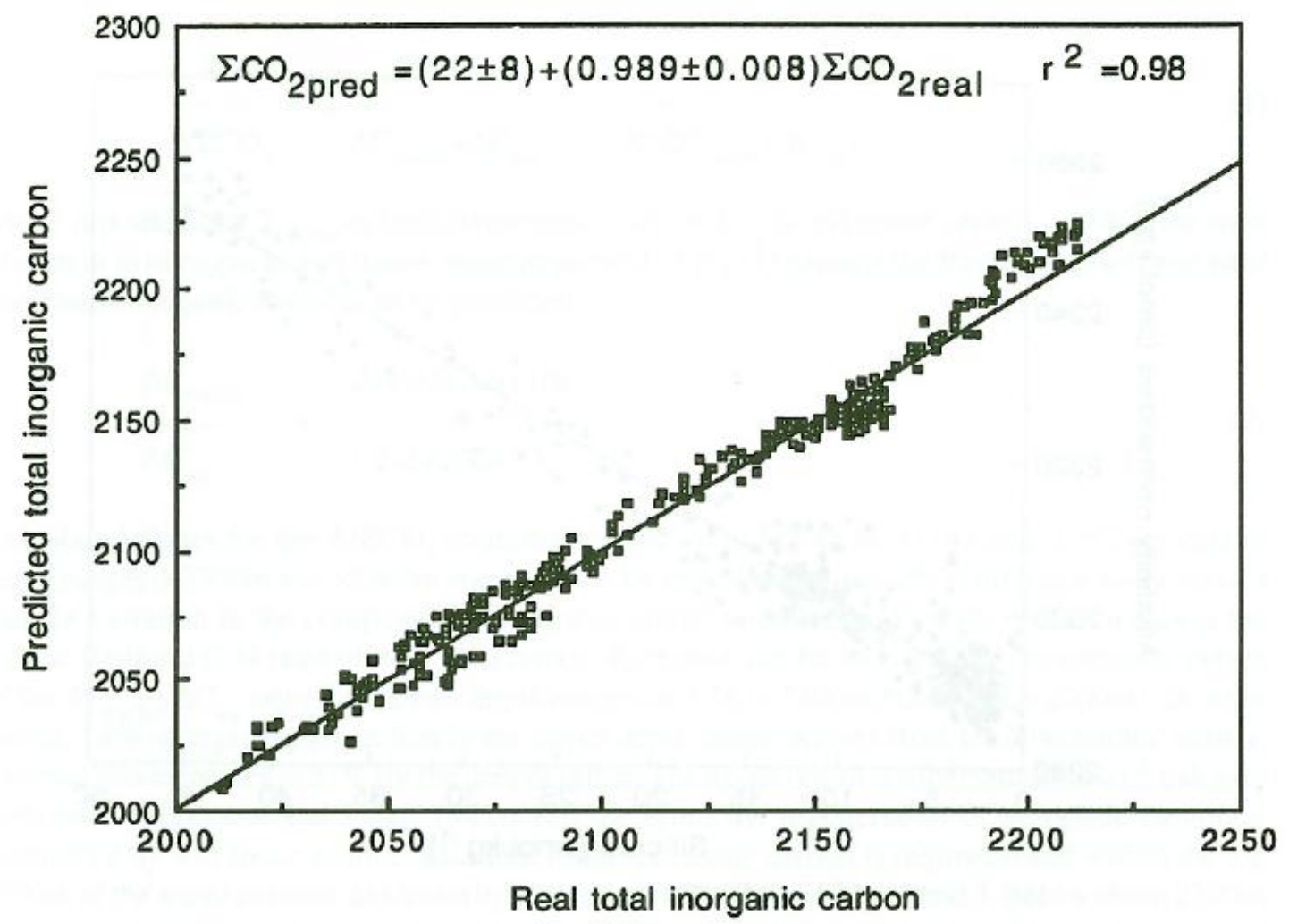

FIGURE 7 


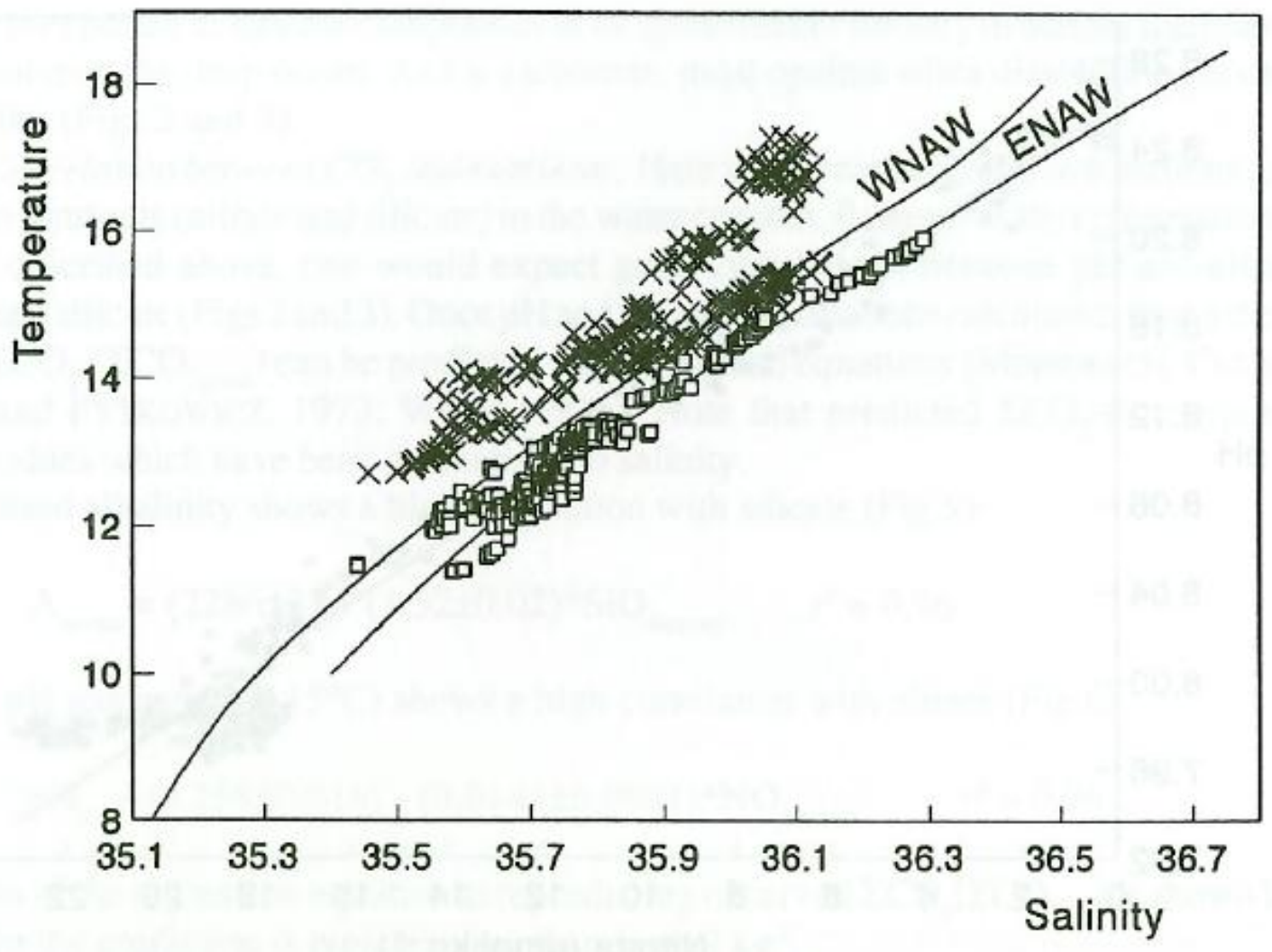

FIGURE 8 

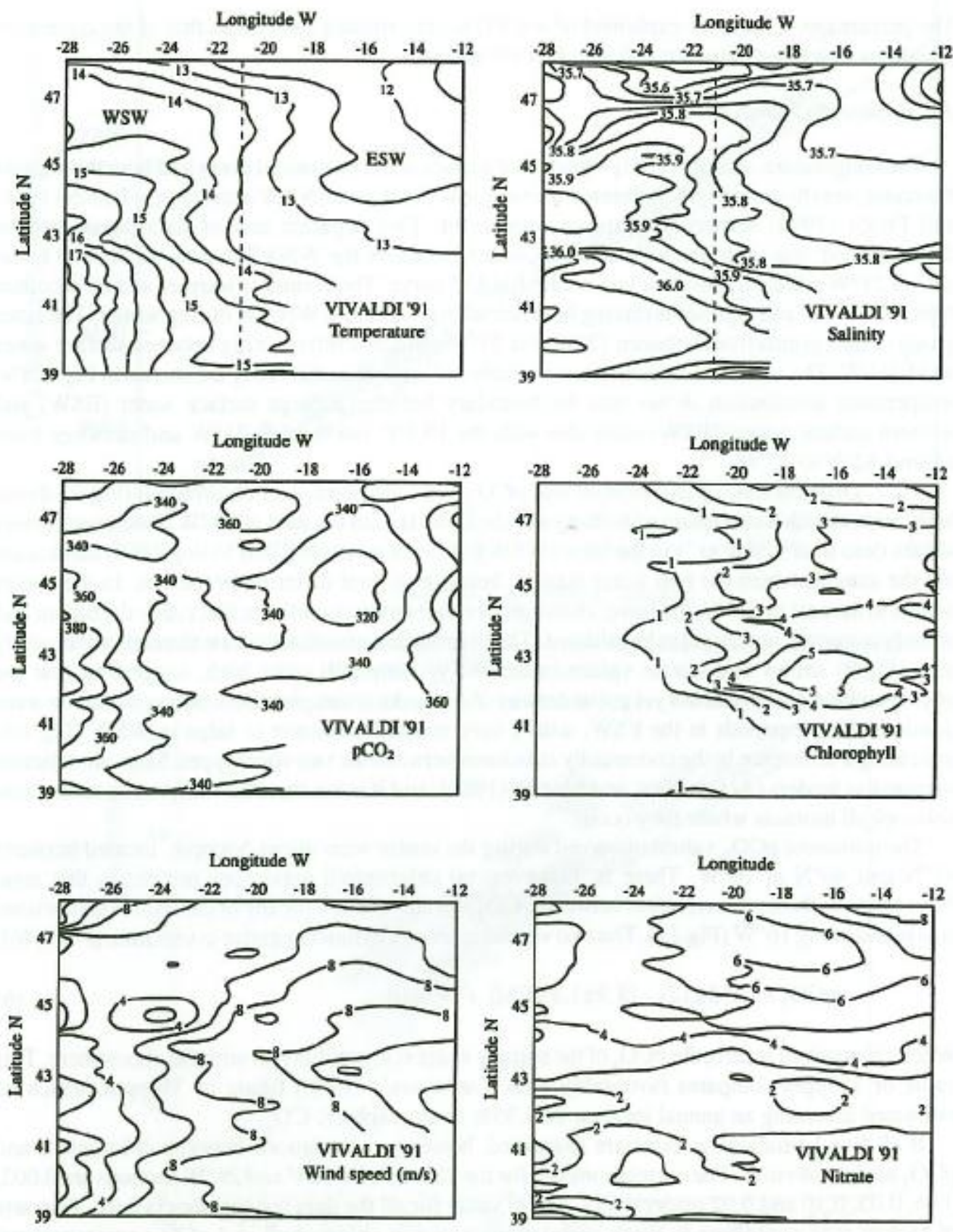

FIGURE 9 


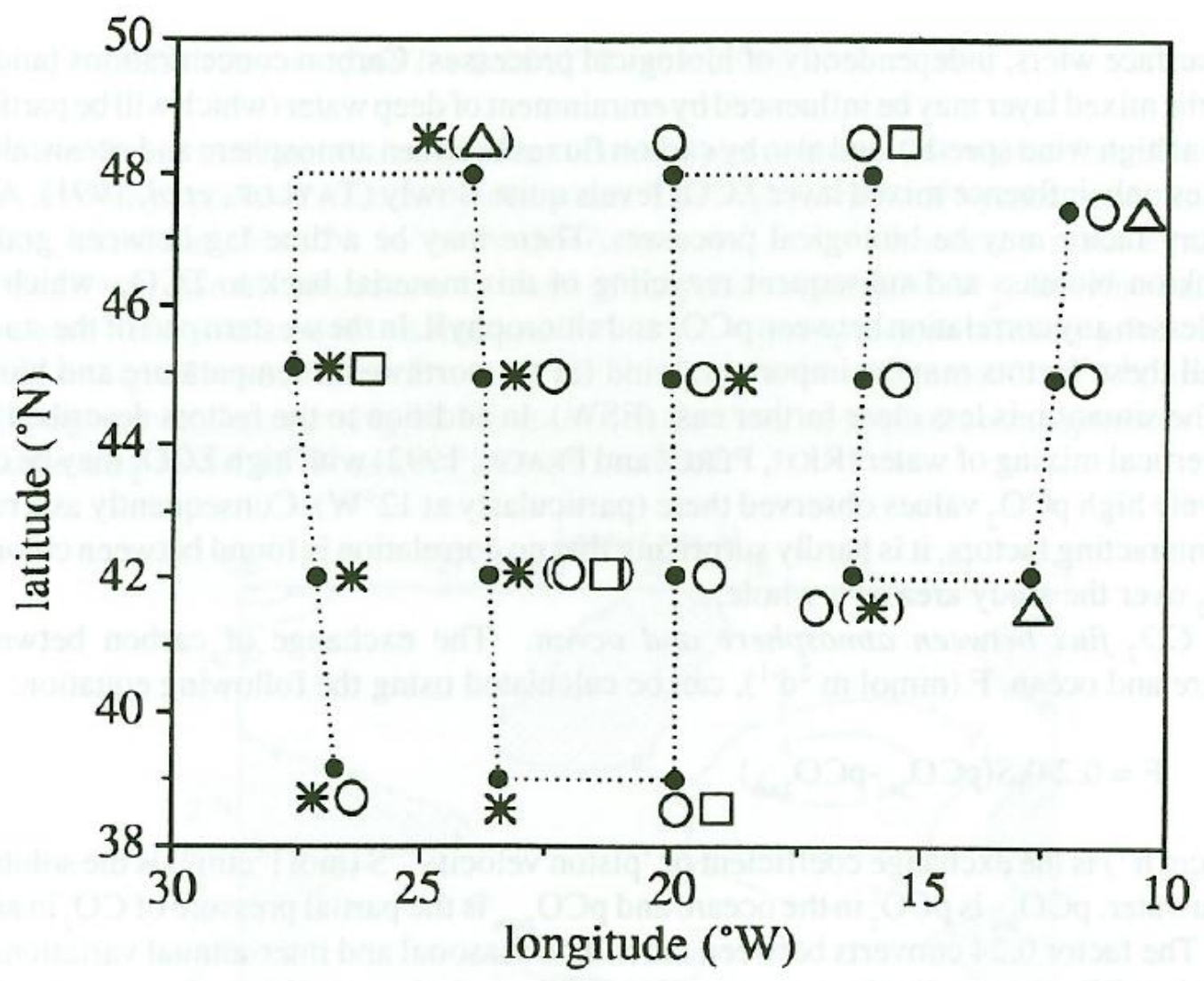

FIGURE 10 


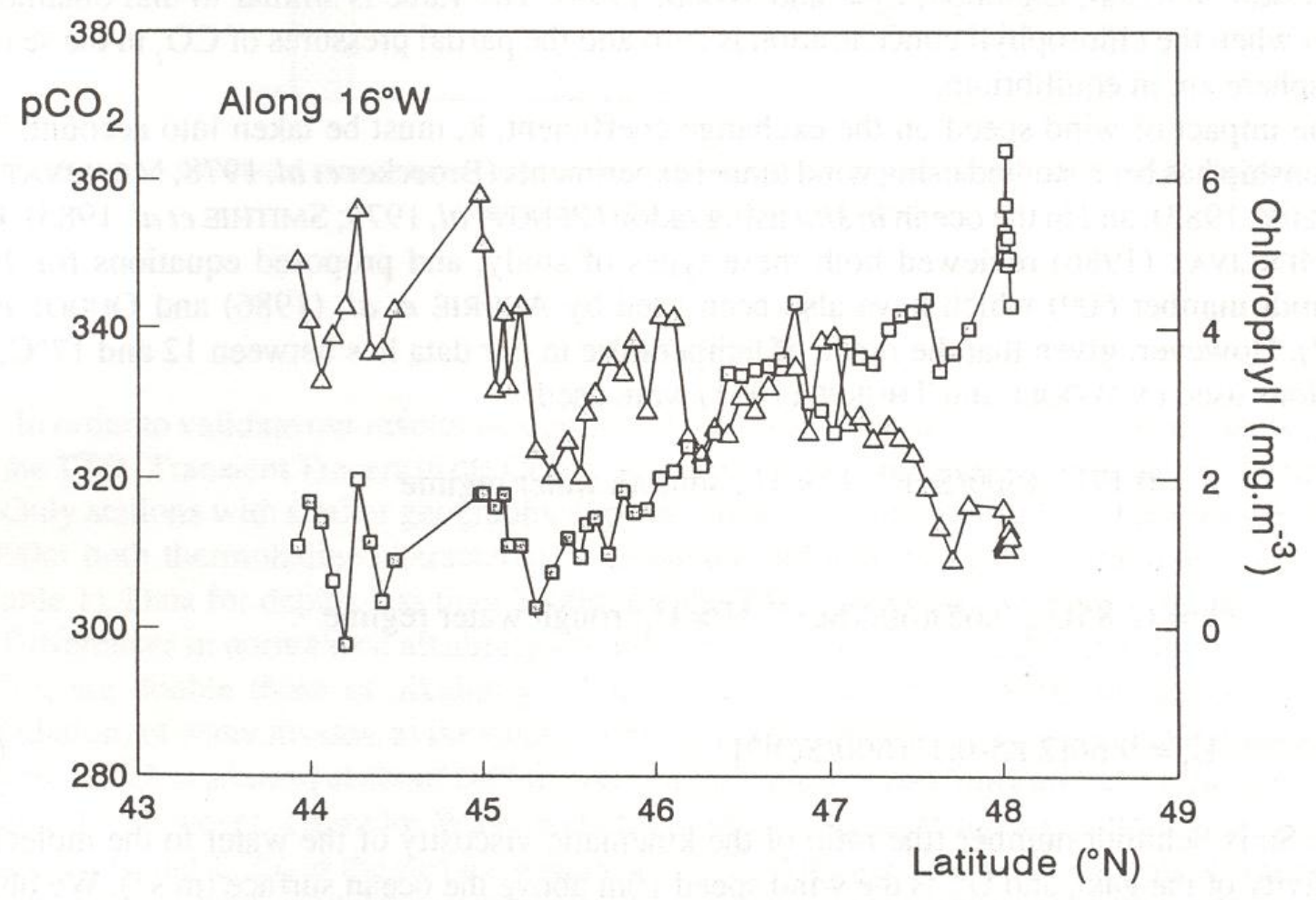

FIGURE 11 


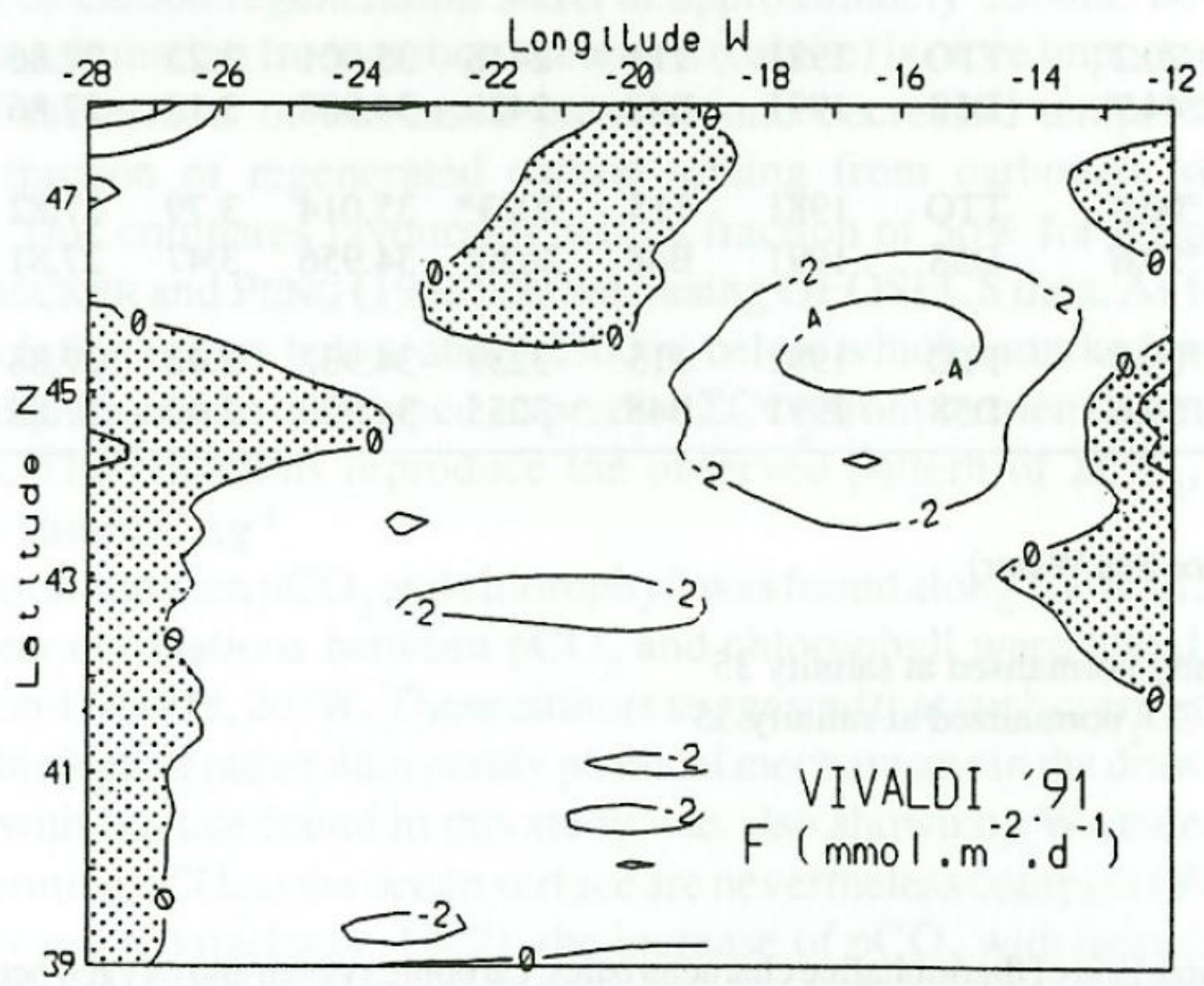

FIGURE 12 